Gut, 1987, 28, S1, 19-23

\title{
Neurotensin induces hyperplasia of the pancreas and growth of the gastric antrum in rats
}

\author{
G E FEURLE, B MÜLLER, AND E RIX \\ From the Medizinische Poliklinik, University of Heidelberg, Heidelberg, F R Germany
}

SUMMARY We investigated whether chronic subcutaneous infusion of neurotensin during 14 days would affect pancreatic and gastric growth of rats. In another experiment, neurotensin $(836 \mathrm{pmol} /$ $\mathrm{kg}$ ) was injected intraperitoneally three times a day for three days in 12 rats. Thereafter, pancreatic DNA and in vitro incorporation of ${ }^{3} \mathrm{H}$-thymidine into pancreatic DNA was determined. Long term infusion of $282 \mathrm{pmol} / \mathrm{kg}$ neurotensin induced an increase of pancreatic weight, DNA, and pancreatic polypeptide, whereas pancreatic protein, RNA, amylase and lipase contents were not increased. In relation to DNA, even these parameters were significantly depressed. Insulin remained unchanged. Neurotensin, therefore, caused hyperplasia of the pancreas. Intraperitoneal injection of neurotensin induced an increase of pancreatic DNA content and stimulated ${ }^{3} \mathrm{H}$-thymidine incorporation into DNA, whereas caerulein only augmented ${ }^{3} \mathrm{H}$-thymidine incorporation. Moreover, long term neurotensin infusion led to a rise in protein concentration and an increase in the thickness of the gastric antrum; antral DNA concentration was insignificantly stimulated. Neurotensin, therefore, can act as a trophic factor on pancreas and gastric antrum of the rat.

One of the many actions of neurotensin is its stimulatory effect on exocrine pancreatic secretion. ${ }^{1-3}$ Because other pancreatic secretagogues, such as cholecystokinin and secretin, also stimulate pancreatic growth, we investigated the effect of chronic infusion of neurotensin on pancreatic growth. As neurotensin also affects gastric secretion and motility, we further examined the effect of long term administration of neurotensin on the stomach.

\section{Methods}

ANIMALS

Alzet osmotic minipumps delivering 0.465 $\pm 0.023 \mu \mathrm{l} /$ $\mathrm{h}(\mathrm{M} \pm \mathrm{SD})$ for 14 days were prepared to pump 43 or $282 \mathrm{pmol} / \mathrm{kg} / \mathrm{min}$ neurotensin subcutaneously in 20 male Wistar rats. The control group consisted of 10 Wistar rats from the same litter in which plastic cylinders with the same size and shape as the minipumps had been implanted. Fourteen days after implantation, the rats were killed by neck dislocation, the pancreata and stomachs were removed, weighed, and frozen. Blood taken by cardiac puncture was centrifuged, the plasma was stored at $-20^{\circ} \mathrm{C}$ until assayed. The frozen tissue was homogenized in

Address for correspondence: Prof Dr G E Feurle, Stadtkrankenhaus, D-5450 Neuwied, Marktstrasse 74, FR Germany. phosphate buffer with an Ultraturrax and a Potter instrument. Protein was determined according to Lowry $e a^{4}$ using human serum albumin as standard. DNA was measured according to Giles and Myers ${ }^{5}$ using calf thymus DNA as standard. RNA was determined according to the Munro-Fleck ${ }^{6}$ modification of the Schmidt-Thannhauser method. Alphaamylase and lipase were determined using the Phadebas amylase test or the Boehringer Mannheim Monotest. Pancreatic polypeptide was determined by radioimmunoassay. ${ }^{7}$ Insulin was determined with the Phadeseph ${ }^{\mathrm{TM}}$ insulin RIA kit (Pharmacia, Uppsala/Sweden). Plasma neurotensin was determined by radioimmunoassay. ${ }^{8}$ One half of the stomachs was frozen for determination of DNA and protein as described above; the other half was fixed with Bouin's solution, embedded in paraffin, cut perpendicularly in $5 \mu \mathrm{m}$ sections and stained with haematoxylin-eosin. The thickness of the mucosal and muscular layers was determined with a caliper lens at 3 points in a defined distance from the ridge between rumen and corpus.

Thirty six male Wistar rats (approx. $100 \mathrm{~g}$ ) received intraperitoneal injections of neurotensin $(836 \mathrm{pmol} /$ $\mathrm{kg}$ ), caerulein $\left(148 \mathrm{pmol} \times \mathrm{kg}^{-1}\right)$, or $0.5 \mathrm{ml}$ saline every eight $h$ for three days. Thereafter and subsequent eight $h$-fast, the rats were killed, the pancreata were minced with a scalpel, and incubated for $30 \mathrm{~min}$ at 


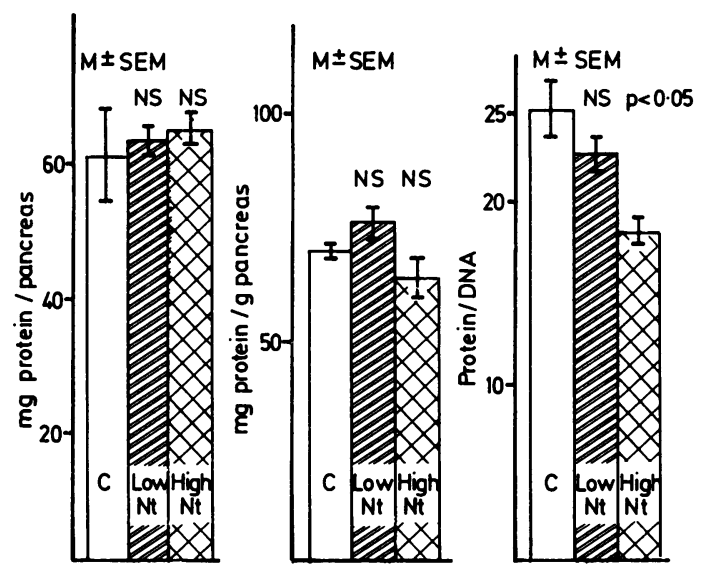

Fig. 1 Protein content, protein concentration, and protein per $\mathrm{mg}$ DNA in rat pancreas after 14 day subcutaneous infusion with 43 and $282 \mathrm{pmol} / \mathrm{kg}$ neurotensin and in control rats.

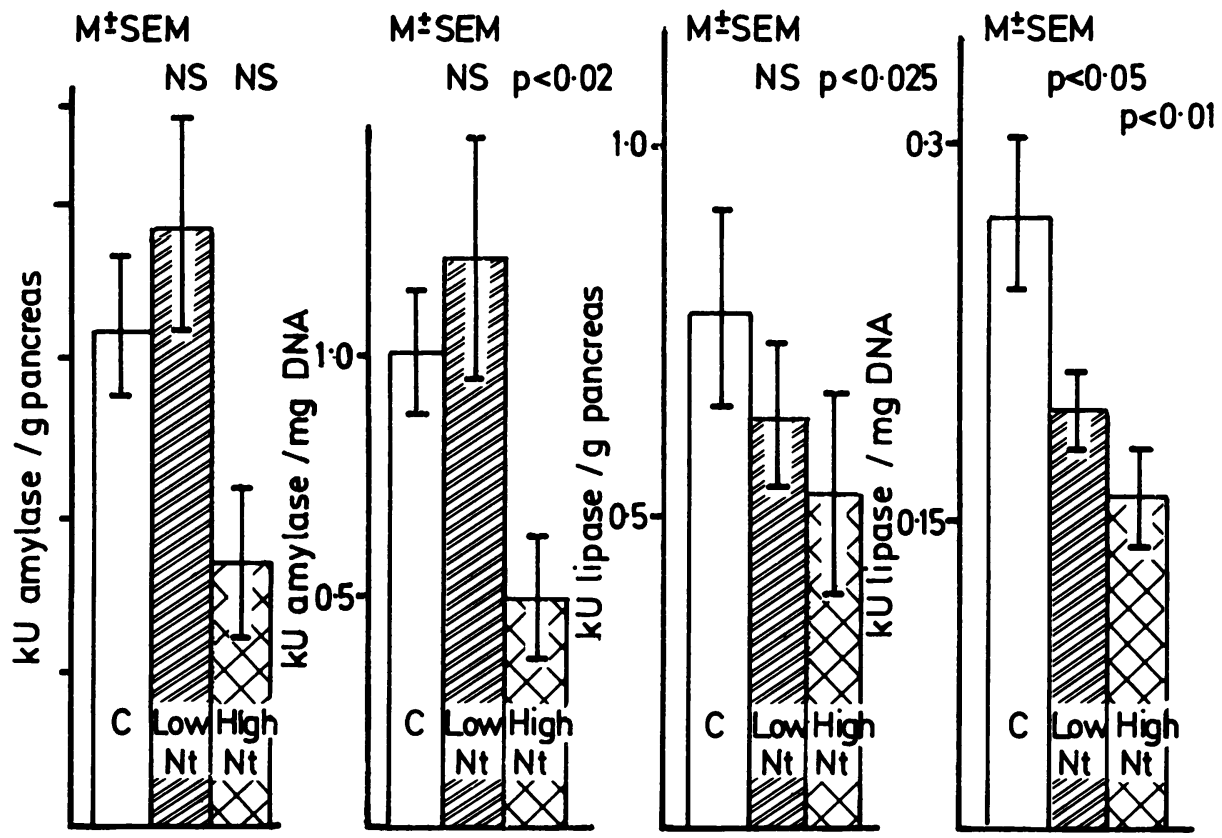

Fig. 2 Alpha-amylase and lipase content per $g$ pancreas and per $m g$ DNA after 14 day subcutaneous infusion of 43 and $282 \mathrm{pmol} / \mathrm{kg}$ neurotensin and in control rats.

Table 1 Pancreatic polypeptide (PP), DNA and insulin content in the pancreas of rats stimulated by a 14 day subcutaneous infusion of 2 different doses of neurotensin with minipumps and of control rats.

\begin{tabular}{|c|c|c|c|c|c|}
\hline & $\begin{array}{l}P P \\
n g / \text { pancreas }\end{array}$ & $\begin{array}{l}p p \\
n g / g \text { pancreas }\end{array}$ & $\begin{array}{l}\text { DNA } \\
\text { mg/pancreas }\end{array}$ & $\begin{array}{l}\text { DNA } \\
\text { mg/g pancreas }\end{array}$ & $\begin{array}{l}\text { Insulin } \\
\text { mU/pancreas }\end{array}$ \\
\hline $\begin{array}{c}\text { control } \\
\text { low NT } \\
\text { high NT }\end{array}$ & $\begin{array}{l}2.40 \pm 0.32 \\
3.77 \pm 0.43^{*} \\
7.04 \pm 1.72 \dagger\end{array}$ & $\begin{array}{c}2.89 \pm 0.38 \\
4.5 \pm 0.55 \\
6.95 \pm 1.72 \dagger\end{array}$ & $\begin{array}{l}2.5 \pm 0.13 \\
2.8 \pm 0.10 \\
3.6 \pm 0.26^{*}\end{array}$ & $\begin{array}{c}2.88 \pm 0.15 \\
3.4 \pm 0.19 \\
3.52 \pm 0.21 \dagger\end{array}$ & $\begin{array}{l}1 \cdot 2 \pm 0.3 \\
1.3 \pm 0.4 \\
1.2 \pm 0.4\end{array}$ \\
\hline
\end{tabular}

${ }^{*} \mathrm{p}<0.05 ; \nmid \mathrm{p}<0.005 ; \mathrm{M} \pm$ SEM 

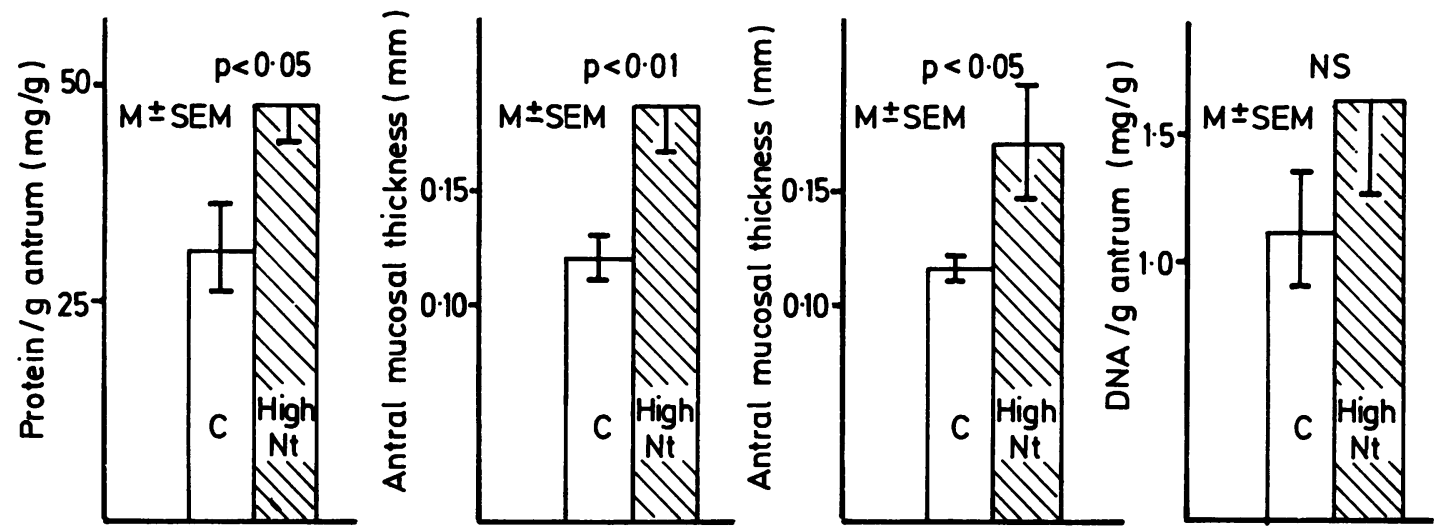

Fig. $3282 \mathrm{pmol} / \mathrm{kg} / \mathrm{min}$ neurotensin (high $\mathrm{Nt}$ ) subcutaneously for 14 days led to a significant rise of protein concentration in the gastric antrum, the thickness of gastric antral muscularis and mucosal layer was increased. There was a tendency for stimulation of antral DNA concentration.

$37{ }^{\circ} \mathrm{C}$ in medium 99 (Gibco), gassed with $95 \% \mathrm{O}_{2}$, $5 \% \mathrm{CO}_{2}$, with added $50 \mu \mathrm{Ci} 5^{\prime}{ }^{3} \mathrm{H}$-thymidine (Amersham). The reaction was stopped by $0.4 \mathrm{M}$ perchloric acid containing $5 \mathrm{mM}$ carrier thymidine. Thereafter, the pancreata were extracted for DNA as described above. ${ }^{3} \mathrm{H}$-activity in the DNA extracts was determined with a scintillation counter.

Light and electron microscopy of the pancreas was performed with conventional techniques.

\section{Results}

Mean neurotensin plasma concentrations in the control group were $137 \pm 8 \mathrm{pg} / \mathrm{ml}(\mathrm{M} \pm \mathrm{SEM})$. After the infusion of $43 \mathrm{pmol} / \mathrm{kg} / \mathrm{min}$ exogenous neurotensin, mean plasma concentrations rose to $170 \pm 21$ $\mathrm{pg} / \mathrm{ml}$, and after infusion of $282 \mathrm{pmol} / \mathrm{kg} / \mathrm{min}$ to $268 \pm 21 \mathrm{pg} / \mathrm{ml}(\mathrm{p}=0.001)$. While the weight gain in all rats was similar, pancreatic weight was significantly higher in the group that received the high dose of neurotensin (control $0.87 \pm 0.03 \mathrm{~g}$ neurotensin $1.02 \pm 0.004 \mathrm{~g} ; \mathrm{M} \pm$ SEM $\mathrm{p}<0.05$ ). Total DNA and DNA concentration per gram pancreas was significantly increased in the high dose group (Table). Pancreatic polypeptide concentration rose significantly in both groups, whereas insulin concentration remained unchanged (Table). Pancreatic protein, enzymes, and RNA were not raised, they decreased significantly in relation to pancreatic DNA (Figs 1, 2). The weight of the stomachs was not affected by neurotensin infusion. The high neurotensin dose, however, led to an increase in the thickness of the muscular and mucosal layers of the antrum (Fig. 3). Moreover, protein/g antrum was significantly, DNA/g antrum insignificantly increased. Thickness of the gastric wall layers, protein, and DNA, however,

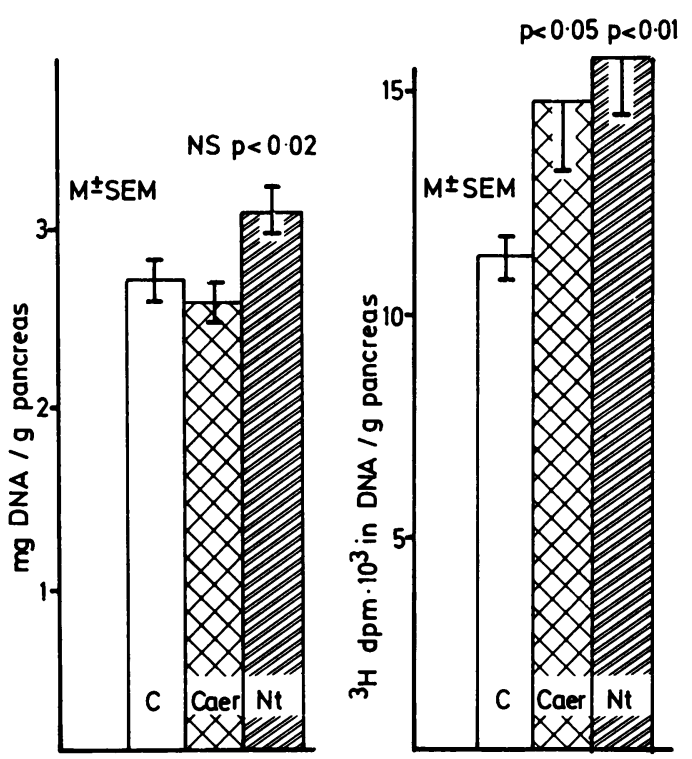

Fig. 4 Three day intraperitoneal injection of neurotensin significantly increased pancreatic DNA concentration. The in vitro incorporation of ${ }^{3} \mathrm{H}$-thymidine into pancreatic DNA was stimulated significantly by the three day treatment with caerulein (Caer) (148 pmol/kg q8 h), and neurotensin (Nt, $836 \mathrm{pmol} / \mathrm{kg} \mathrm{q} 8 \mathrm{~h}$ ).

remained unchanged in the body of the stomach (not shown).

In the neurotensin injection study, mean DNA/g pancreas increased significantly from $2 \cdot 7 \pm 0 \cdot 1$ to $3 \cdot 1 \pm 0.1 \mathrm{mg} / \mathrm{g}$ pancreas $(\mathrm{M} \pm \mathrm{SEM}, \mathrm{p}<0.02)$. Incorporation of tritiated thymidine into DNA was significantly stimulated by caerulein and neurotensin (Fig. 4). 

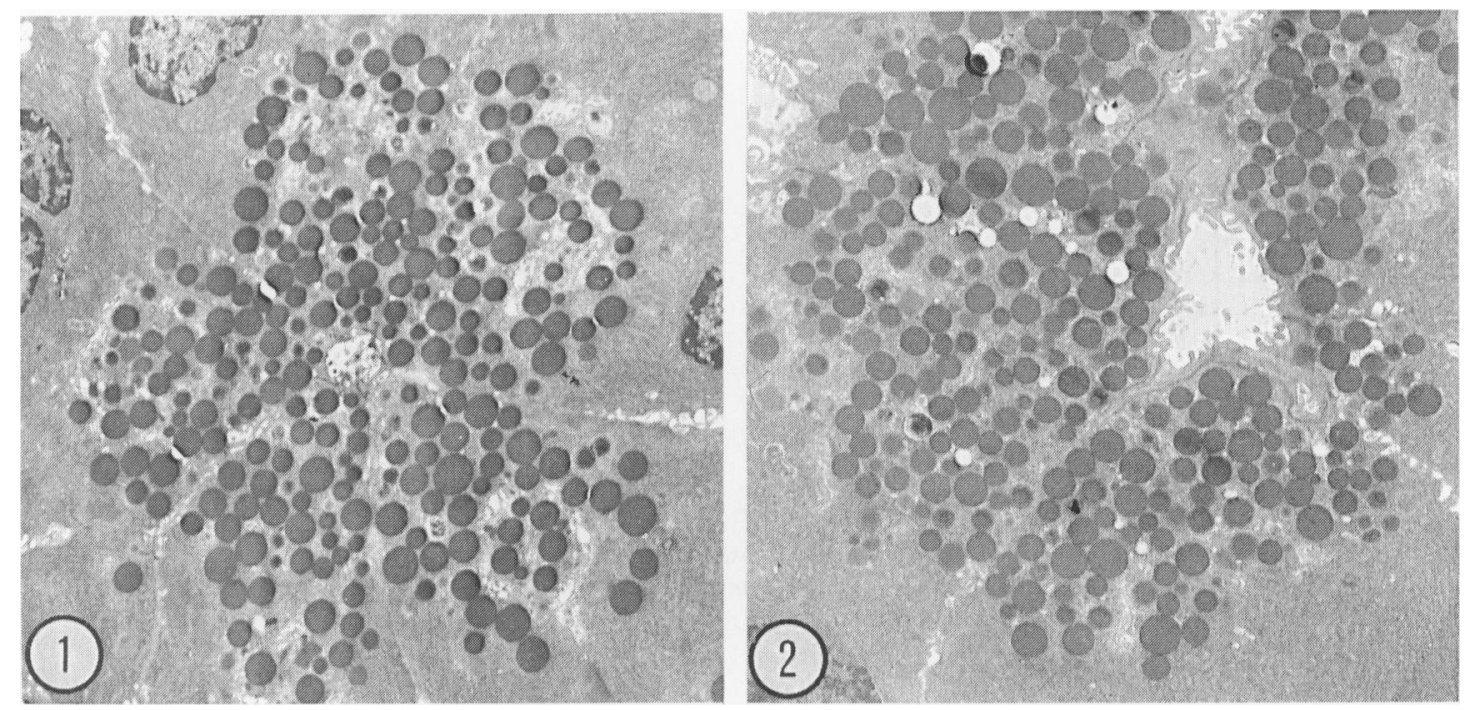

Fig. 5 Electronmicroscopy of a pancreatic acinus of a rat treated with the high dose of neurotensin (2) and of a control animal (1). Number, size, and electron density of the granules apparently are unchanged.

Morphometry on the microscopical level indicated no discernable change of the areas containing enzyme granules within the acinar cells. On electronmicroscopy the size, number, and electron density of the granules were unchanged after the high dose of neurotensin when compared with control pancreas (Fig. 5).

\section{Discussion}

This study shows that chronic parenteral neurotensin, unlike CCk, which leads to an increase of pancreatic weight, DNA as well as pancreatic RNA and protein, ${ }^{9}$ selectively increased pancreatic weight and DNA. Enzymes and RNA were reduced in relation to DNA. In addition, neurotensin induced pancreatic cell proliferation shown by incorporation of ${ }^{3} \mathrm{H}$-thymidine into DNA. Whereas chronic CCk treatment thus leads to pancreatic hypertrophy as well as hyperplasia, neurotensin seemed to induce pancreatic hyperplasia only. An additional hypertrophic effect seems unlikely although the net unchanged pancreatic enzyme content may be the consequence of enzyme depletion induced by a continuing infusion of neurotensin. The RNA content, however, was also unchanged. The unaltered content of enzymes in the pancreas (when not related to DNA) also in accordance with the morphological data indicates that release of enzymes after long term neurotensin infusion is in balance with synthesis of enzymes. The unchanged size and number of enzymes granules in the presence of an increased content of DNA, therefore, supports the conclusion of a predominantly hyperplasiogenic effect of neurotensin. Hence, pancreatic secretagogues seem to regulate pancreatic secretion as well as pancreatic growth. In view of the presence of neurotensin immunoreactive nerves within the pancreas, ${ }^{10}$ a neural action of neurotensin on secretion as well as on growth seems also possible. The action of neurotensin may, however, be indirect. The most sensitive pancreatic parameter after two weeks administration of neurotensin was pancreatic polypeptide which itself has been reported to increase DNA synthesis in the rat pancreas. ${ }^{11}$ It is, therefore, very possible that neurotensin affects pancreatic proliferation indirectly via pancreatic polypeptide.

Furthermore, neurotensin led to an increase in the thickness and the protein concentration of the gastric antrum. One possible mechanism of this action is that neurotensin reduces gastric emptying ${ }^{12}$ probably by inducing retention of gastric contents. Gastric stasis and dilatation, however, led to hypertrophy of the gastric antrum. ${ }^{13} \mathrm{An}$ indirect effect of neurotensin on the stomach as well, therefore, would appear possible.

It is unknown whether these effects are pharmacologic or physiologic. At any rate neurotensin should be added to the list of peptides which can induce growth of pancreas and stomach in the rat.

\section{References}

1 Baća I, Mittmann U, Feurle GE, Müller T, Haas M. Organ blood flow and exocrine pancreatic function after 
intravenous infusion of neurotensin. Langenbecks Arch Chir Forum 1981; 285-88.

2 Baća I, Feurle GE, Schwab A, Mittmann U, Knauf W, Lehnert T. Effect of neurotensin on exocrine pancreatic secretion in dogs. Digestion 1982; 23: 174-83.

3 Khalil T, Fujumura M, Greeley, Jr GH, Townsend, Jr CM, Thompson JC. Neurotensin stimulates pancreatic exocrine secretion in rats. [Abstract]. Regul Peptides 1986; 15: 279-84.

4 Lowry, OH, Rosebrough NJ, Lewis Farr A, Randall RJ. Protein measurement with the folin phenol reagent. $J$ Biol Chem 1951; 193: 265-75.

5 Giles KW, Myers A. An improved diphenylamine method for the estimation of deoxyribonucleic acid. Nature 1965; 206: 93.

6 Munro HN, Fleck A. Recent developments in the measurement of nucleic acids in biological materials. Analyst 1966; 91 : 78-88.

7 Feurle GE, Büchler M, Helmstädter V. Gastric and enteral pancreatic polypeptide (PP) immunoreactivity in the dog. Acta Histochem 1986; 77: 151-8.
8 Feurle GE. Physiological and pathological aspects of a neuro-endocrinological principle: neurotensin. Frontiers Horm Res 1984; 12 : 157-67.

9 Johnson LR. Effects of gastrointestinal hormones on pancreatic growth. Cancer 1981; 47: 1640-5.

10 Feurle GE, Reinecke M. Neurotensin interacts with carbachol, secretin, and caerulein in the stimulation of the exocrine pancreas of the rat in vitro. Regulatory Peptides 1983; 7: 137-43.

11 Greenberg GR, Mitznegg P, Bloom SR. Effect of pancreatic polypeptide on DNA-synthesis in the pancreas. Experientia 1977; 33: 1332-3.

12 Blackburn AM, Fletcher DR, Bloom SR, Christofides ND, Long RG, Fitzpatrick ML, Baron JH. Effect of neurotensin on gastric function in man. Lancet 1980; 1 : 987-9.

13 Feurle GE, Tischbirek K, Helmstaedter V. Intragastric balloons causing gastric hypertrophy, G-cell hyperplasia, and raised serum gastrin levels in rats. Lancet 1982; ii: 386. 